\title{
FILOLOOGIA, MIDA ENAM POLE
}

\author{
LINNAR PRIIMÄGI
}

$\mathrm{J}$ oel Sang andis mulle üles kirjutada filoloogia hääbest meie nüüdiskultuuris, probleemist, mida olen kahetsedes seiranud, tõdedes, et klassikalise üldhariduse kustudes kaob midagi kallist - vaimumaailm, milles minu põlvkonna humanitaarid on kasvanud ja kodunenud (Priimägi 2010a). Põlvkondade vahetus, paratamatus, öeldakse. X-generatsioonist on saanud Y-generatsioon ja sellest omakorda Z-generatsioon. Rooma tähestik läbi. Kas nüüd peaks algama kõik uuesti, uuel ringil, A-st? Kas peaksime uskuma Vergiliust, kes neljandas ekloogis lubab, et mitmeastmelise allakäigu lõpetab järsk kosmiline pööre ja taastub maailma kuldne algseis? Või on too väärtuslik osa Euroopa vaimukultuurist, mida me südantsoojendavalt nimetame filoloogiaks, juba pöördumatult läinud? Peab tegema inventuuri.

Iroonilis-melanhoolsel Erich Kästneril räägib säärasest „varade ülevaatuse” vajadusest luuletus „Saabumine Itaaliast” (1929): „Nii, olen onnnelikult jälle siin. / Lukk endine, taas astun korterisse... / Kuni ma Pisa torni vaatasin, / on keegi nägu siia murdnud sisse. // Mis omasin, on meelest läinud seni, / pean meenutama, mis mul kõik siin oli..." Mida muud siis meiegi - meenutagem!

\section{MÄÄRATLUS}

Isegi sõnale „filosoofia” andsid stoikud kuus mõtestust, mistõttu defineerigem filoloogia, pööramata tähelepanu segadusele võõrastes peades. Filoloogia on teadus, mis uurib tegelikkuse transformatsiooni tekstiks ja vice versa. Filoloogia tegeleb sõnastatavusega, tema ese on kõik, mille kohta saab kuidagi midagi ütelda.

Filoloogia eristab tekste ja reaalsust - mitte kui substantsiaalseid antusi, vaid kui funktsionaalseid rolle: ka tekst, millest või mille kohta filoloog teeb uue teksti (tõlke, kommentaari vms), esineb (tekstilise) reaalsusena, tema ajel valmiv uus tekst aga (meta)tekstina. Või kui mõista teksti universaalselt, ükskõik millise tekstuurina, siis saab ka filoloogiat määratleda universaalselt kui metatekstiteadust.

\section{Universaalne humanitaarteadus}

Kitsamas mõttes tekst, sõnatekst, on filoloogia tuummõiste. Aga filoloogia ei tegele mitte ainult tekstoloogiaga kui kirjalike tekstide optimeerimisega, kanoonilise tekstikuju „taastusega” (tegelikult küll konstruktsiooniga) võrdleva tekstikriitika abil. Filoloogiat huvitab samavõrd suuline kõne. Niisiis inimese keeleline käitumine üleüldse. 
Keelepsühholoogia uurib inimese keelelise käitumise ajendeid ja võimalusi ning on seega filoloogia tähtis abiteadus, millel ilma filoloogiata puuduks igasugune sisu ja mõte.

Filoloogiat huvitab, kuidas inimene tõlgib tegelikkust loomulikku keelde ja tagasi. „Tõlgib” ei tähenda siin filoloogia samastust kitsalt tõlketeooriaga, mis uurib seda, kuidas üks loomulikus keeles tekst vahendatakse teise loomulikku keelde, aga tõlketeooria on muidugi filoloogia osa.

Et tegelikkus on väga avar mõiste, hõlmates nii objektiivse kui ka subjektiivse reaalsuse, siis võib filoloogiat pidada humanitaarseks universaalteaduseks või universaalseks humanitaarteaduseks.

\section{Filoloogiline entsüklopedism}

„Ühekülgne haridus pole mingi haridus. Lähtuda tuleb küll ühestainsast punktist, aga minema peab mitmes suunas. Ükskõik, kas ollakse omandanud matemaatiline või filoloogiline või kunstiline haridus, peaasi, et see on olemas; aga haridus ei saa seisneda nendes teadustes üksi. Üksikteadused on nagu meeleorganid, millega me esemeid kaeme... nii on naeruväärne korvata matemaatikaga muid tunnetusviise ja vice versa..." ütles Goethe 24. VII 1807 Riemerile.

Filoloogia sündis Aleksandrias universaalteadusena, mis tegeles kõigega - mitte üksnes keele ja kirjandusega, vaid ka astronoomia, meditsiini ja muuga -, kus kasutatakse sõnu, inimkeelt. Museioni raamatukogu, riigipalgaliste teadlaste linnak, töötas nagu teaduste akadeemia. Selle liikmed olid entsüklopedistid: Suetoniuse teatel nimetati esimeseks filoloogiks matemaatik Eratosthenest, kes arvutas välja Trooja sõja lõpuaasta (-1183), maakera suuruse ning joonistas esimese kreeka maailmakaardi; Samothrake Aristarchos, kelle nimi sai „kriitiku” sünonüümiks, konstrueeris koinee loogilise grammatika ja rekonstrueeris tekstide õigsust; Theophrastos, „botaanika isa”, koostas ka „Iseloomud”, millest uusatika komöödia ammutas oma psühholoogilised tüübid (karakterid) ja millest sai nüüdisaegse imagoloogia (kuvanduse) õppematerjal. Aleksandrias sündis Kallimachosel antiikkirjanduses uut tüüpi, õpetatud luule ning Apollonios Rhodios kirjutas „Argonautika”, mille peen psühhologism paneb kohati (vv III 648-651, 766-769) õnnest hõiskama. Kes soovib veel üht piltlikku määratlust: filoloogia tegeleb kõigega, mille kohta Museionis võis leiduda raamat.

Ainult filosoofiat Museionis ei viljeldud - seda asendas edukalt filoloogia kui tõeotsing keeletsi ja keeliti. Hellenistliku müstitsismi või ataraksiaõpetusega polnuks seal ka midagi peale hakata. Hiljem väitis Arnauld, et filoloogia meetod ongi filosoofiline, aga sellesse arutellu laskumata tõdegem, et filoloogiat huvitab filosoofia üksnes kui subjektiivne tegelikkus teksti kujul.

\section{Filoloogia ja semiootika}

Filoloogia õitses viimati semiootika (või parem: semioloogia) nime all. Émile Benveniste (1974: 78) sõnastas selle alusliku tõe: „Ühiskonnas käibivaid märke saab täielikult interpreteerida keelemärkide abil, aga mitte vastupidi.” 
Filoloog Saussure tegeles keelega, filoloog Jakobson keele ja kirjandusega, filoloog Lotman keele, kirjanduse ja kultuuriga. Nad teenisid teadust, ja mitte kui orjad või moonakad, vaid kui suveräänid. Teaduslikku suveräänsust võeti enesestmõistetavusena, millega käsutati eriala vaimupärandit ja millest tulenes mõttevabadus, avastuste sundimatus.

Tartu Riiklikus Ülikoolis kandis seda vaimu veel Lotmani Tartu-Moskva koolkond, selle ammendudes algas filoloogia loojang Eestis. Järelvägi konstrueerib semiootilisi keerdkäike, arvates, et labürint on liiklusvahend.

Filoloogia võttis seitsmest vabakunstist üle triiviumi, jättes kvadriiviumi (numbrilised distsipliinid aritmeetika, geomeetria, muusika ning astronoomia) reaalteaduste vallaks. Semiootikud on osutanud, et triiviumi aineid saab vastavusse viia märgisüsteemi kolme dimensiooniga: grammatika = paradigmaatika, loogika $=$ süntagmaatika, retoorika $=$ pragmaatika. Need on ühtlasi filoloogiale huvi pakkuva keele ja tegelikkuse transformatsiooni põhivormid: (1) tekst $\rightarrow$ tekst (grammatika, paradigmaatika), (2) tekst $\rightarrow$ tegelikkus (retoorika, pragmaatika), (3) tegelikkus $\rightarrow$ tekst (loogika, süntagmaatika). Neljanda võimalusega (tegelikkus $\rightarrow$ tegelikkus) filoloogia ei tegele, jättes selle valdkonna reaalteadustele.

\section{Filoloogia ja matemaatika}

Matemaatika ja filoloogia erinevad teineteisest põhimõtteliselt. Esimese perimeeter peab iga teadustööga kasvama: matemaatik ründab oma teaduse piire ega korda enam kunagi tehtud avastusi. Iga järgmine põlvkond - sit venia verbo - tallab eelkäijate saavutused jalge alla (Newton: „Kui ma olen näinud kaugemale, siis hiiglaste õlul seistes"). Matemaatika ei vaja vanu lahendusi, seal on tähtis esimuse küsimus (Newton vs. Leibniz infinitesimaalarvutuses). Seetõttu on matemaatikas mõtet ka antitsipatsiooni mõistel (Wiener 1969: 17: „Paljud mehed on oma ajast intuitiivselt kaugele ette jõudnud, ja heaks näiteks selle kohta on matemaatiline füüsika. Gibbs tõi tõenäosuse füüsikasse ammu enne, kui oli olemas vastav teooria temale vajalike tõenäosuste kohta"). Filoloogias asendab „antitsipatsiooni” kas „reministsents” või „rekapitulatsioon”: meie teadus kohustab meid kõiki eelnenud avastusi teadma ja meenutama. Matemaatiku mälu on protseduuriline, filoloogi oma semantiline. Filoloogias võib teemasid ikka uuesti käsitleda: väsimatu innuga ja kõikuva huviväärsusega arutatakse näiteks, mis asi on müüt - regenereerimaks müüditeadvust. Piibel on filoloogiliselt ammendamatu. Humanitaarid toovad ikka ja jälle erineva eduga - midagi päevavalgele Goethe „Faustist”, matemaatikul aga ei ole Eukleidese „Elementidest” või Newtoni „Loodusfilosoofia matemaatilistest alustest” enam mitte midagi avastada. Reaalteadused arenevad laiuti ka mateeria sügavusse tungides. Humanitaarteadused ja filoloogia kui nende kuninganna arenevad sügavuti ka inimmõtlemise silmapiiri uurides. Matemaatikas on „erudiidi” mõiste naeru-, filoloogias imetlusväärne.

Kui hiinlasest matemaatik kurdab, et ei sobi oma Ameerika töökeskkonda, sest seal tõtatakse aina vahetama paradigmasid ja valitseb uusavastuse sundus - erinevalt tema traditsioonilisest kultuurist, mis väärtustab ühe paradigma maksimaalset ärakasutust (Kaplinski 2016) -, siis on põhjus just selles, et traditsiooniliselt tugineb hiina kultuur humanitaarsele, filoloogilisele haridussüsteemile. 
Täppisteaduste ja -seaduste nõue on nende paratamatus. Humanitaarteadustes, sh filoloogias, see ei kehti, siin on tegu loogiliselt keerukamate mõttekonstruktsioonidega, kus järelduste tõsikindlus sõltub eeldustest kaudsemal, aga ikkagi mitte loogikavälisel või -kõrvasel moel. Mood asendada loogika filoloogiateaduses „dekonstruktsiooniga” kujutab endast harimatuse maskeeringut.

Keele- ja kirjasüsteemid on digitaalsed, ühikulised. Sellest tõdemusest sündinud matemaatiline filoloogia ulatub keelestatistikast kabalistikani (mida arvuti abil jällegi viljelda ei saa - Baukhage 2005). Ka maia kirja võti leiti matemaatiliselt - kõigepealt dešifreeris Knorozov kalendri. Kuid dešifreeritavuselgi on piir, millest matemaatika üle ei aita. Inkade nöörkirja kombinatoorsed dimensioonid (nööride arv, nööri pikkus, nööri värv, sõlmede hulk, sõlmede koht nööril, sõlmede nööridevaheline kõrvutisus) võimaldavad arutu hulga kombinatsioone. Kiput lugeda oskas vaid see, kes sisu ette teadis.

Filoloog võib tegelda matemaatikaga, ent matemaatiku tegelus filoloogilise ainega jätab pahatihti diletantluse mulje. Viieteistkümnendas Tartu semiootika-köites märgib Juri Lotman (1982: 47) matemaatikute Postnikovi ja Fomenko artikli saateks: „Kahtlusi tekitab oletus, et „sagedamini tsiteeritakse tsiteerijale lähedasi tekste ja kaugemaid tekste tsiteeritakse harvem". 1950. aastate nõukogude kirjandusteaduses erines järsult Tšernõševski ja Dostojevski tsiteeringute sagedus. Kas see tähendab, et ajaline distants nende kirjanike ja tsiteerija vahel oli erinev? Valikuliselt vaatlesime Homjakovi ja Herzeni tekste. Sellest oletusest juhindudes on vahemaa Herzenist XVIII sajandi prantsuse filosoofideni ligikaudu võrdne vahemaaga Homjakovi ja IV-XII sajandi kirikuisade vahel."

Topoloogiliselt peab mõtlema paleograaf, tuvastades maia kirjamärkide graafilisi rööbikuid. Kuid matemaatikast ei ole abi määratlemaks isegi kirja suunda Phaistose kettal (nt Dakota härjanahkadele kirjutati spiraalis mõlemat pidi, kas servast keskele või keskelt serva poole).

Iselugu on, et matemaatika oma kõrgeimas arengujärgus transformeerub humanitaarseks (Brouwer „Elu, kunst ja müstika”, 1905). Kui termodünaamika teine seadus Boltzmanni sõnastuses ütleb: „Mingi oleku tõenäosuse logaritm sõltub võrdeliselt selle oleku entroopiast," siis peab Spengler (1923: 491) nentima: „Siin omandab iga sõna täieliku ning üksnes sisetundega tabatava, mitte kirjeldatava arusaama loodusest." Kus matemaatika arvudest abstraheerub, aga säilib ükskõik milline loogika, seal kannab sõnadest mõtteni viiv tee filoloogia nime. Arvuti ei mõistaks Boltzmanni.

\section{Filoloogia ning eksegeetika}

Eksegeetika on tõlgendus-, väljalugemiskunst. See ei piirdu loomuliku, üldkeelelise, vahetu arusaamaga tekstist, vaid tegeleb alltekstiga. Platon, kes „Riigis” (378 D) taunib kirjanduse amoraalsust, räägib allegooriast: „Jumalate taplused Homerose luules on asjad, mida ei peaks lubama oma riiki ei allegoorilises ega mitteallegoorilises sõnastuses." Eksegeetika algaski Homerose allegoreesi ( $\dot{\alpha} \lambda \lambda \eta \gamma o \rho i \alpha)$ analüüsist (Pergamoni raamatukogu juhataja stoik Krates). Philoni kaudu jõudis see piibli kallale. Origenes sõnastas prog-

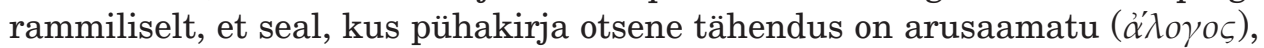
saladuslik ( $\mu v \sigma \tau \iota \kappa o ́ \varsigma)$ või sobimatu, vääritu ( $\dot{\alpha} \delta v \alpha \tau \sigma \varsigma)$, sealt tuleb otsida 
tagamõtet, allteksti - vaimlist tähendust ( $\lambda o ́ \gamma o \varsigma \tau v \varepsilon v \mu \alpha \tau \iota \kappa o ́ \varsigma)$, jumalik-endelist ( $\beta \alpha \theta \dot{v} \tau \varepsilon \rho \circ \varsigma)$, kõrgemale teispoolsusele viitavat ( $\dot{\alpha} v \alpha \gamma \omega \gamma \iota \kappa o ́ \varsigma)$, kujundlik-

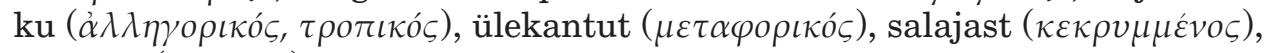
vihjelist ( $\tau v \pi \iota k o ́ \varsigma)$.

Esmalt tehtigi vahet üksnes tekstilisel (verbaalsel) ning alltekstilisel mõttel („me kõneleme Jumala saladusse peidetud tarkusest” - 1Ko 2: 7), hiljem need jagunesid erisugustel alustel veel siinpoolseks ja sealpoolseks. Näiteks toora manitseb: „Ära seo kinni härja suud, kui ta pahmast tallab!” Verbaalne (siinpoolne tekstiline) tähendus lojusest räägibki. Moraalse (siinpoolse alltekstilise) tähenduse sõnastab Paulus (1Ko 9: 9-10): „Kas Jumal hoolitseb härgade eest? Eks ta ütle seda pigem meie pärast? Meie pärast on ju kirjutatud, et kündja peab kündma lootuses ning rehepeksja peksma lootuses, et ta saab sellest osa." - Niisiis, töötegija peab oma töö viljast osa saama. Nagu hiljem võttis põhimõtteks Henry Ford: minu autotehase tööline peab vähemalt nii palju palka saama, et ta ka ise jaksab osta omaenda toodetud auto. Pneumaatiline (sealpoolne) tähendus keelab ära võtta lootust tasule taevariigis.

Dante („Convivio” II, 1) esitab teistsuguse eksegeetika, rääkides neljast tõlgendusviisist: otsesest (litterale), allegoorilisest (allegorica), moraalsest (morale) ning anagoogilisest ehk ülemeelelisest (anagogico, cioè sovrasenso). Allegooriline on Dantel mõistujutu tähendus, moraalseks nimetab ta pedagoogilist interpretatsiooni (kui Kristus läks mäkke kirgastuma, võttis ta kaasa vaid kolm apostlit kaheteistkümnest - mis tähendab, et suuri salaasju tuleb toimetada väheste tunnistajatega), anagoogiline aga, kui tekstis öeldut käsitatakse kristlike sümbolitena: prohveti sõnu Egiptusest põgenemise kohta, et Juuda sai terveks ja vabaks, tuleb mõista nii, et patuseisundist väljunud hing saab terveks ja vabaks omas väes (santa e libera in sua potestate).

Keskajal kujunes välja vaimulik eksegeetiline kvadraat, kus eristatakse esiteks otsest, faktilist või „historiaalset”, st „loosse endasse puutuvat” tähendust, teiseks allegoorilist, millega tagati Vana ning Uue Testamendi tähendusühtsus, kolmandaks moraalset („tropoloogilist”) ehk käitumisjuhislikku ja neljandaks anagoogilist (religioosset-sakramentaalset, ülendavat). Selles võtmes interpreteeris nt Hrabanus Maurus „Jeruusalemma”: otseses tähenduses 'maapealne linn', allegoorilises 'kirik', tropoloogilises 'õige hing', anagoogilises 'taevariik' (Gurevitš 1984: 76).

\section{Filoloogia ning etümoloogia}

Teksti tegelikkuseks transformatsiooni eksegeetiline meetod seisneb tähenduse väljalugemises, mis on retseptsiooni, retoorika ja propaganda ala. Etümoloogia, sama transformatsiooni teine tee, on teksti tähendusse sisselugemise kunst - rekonstruktsioon, millisest tegelikkuse asjaolust sõna on sündinud ja kuidas ta on kujunenud selleks, millena teda kaasajal teatakse ja

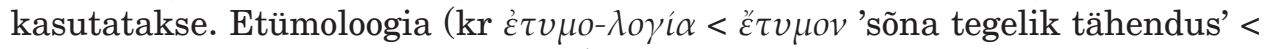

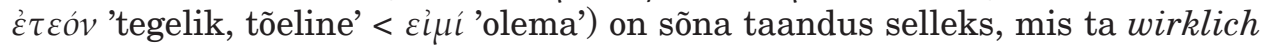
gewesen ist - kui laenata see väljend ajaloolaselt Rankelt.

Etümoloogia taastab sõnataguse tegelikkuse ning osutab sõna tähenduspotentsile. Johannes Joseph Schmidlini prantsuse-saksa sõnastikus (1771/79, jäi pooleli) leidub kuus täpsustavat seletust sõnale hacher (< sks hacken 'hak-

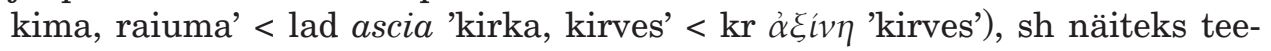


mandilihvimise alal: „Terasest lihvimiskettale noateraga, viiliga või muu riistaga kramme vedama. Teemandipuru (s.o teemanditolm) koguneb lihvimisel nendesse krammidesse ja moodustab justkui viili, mis ketta kiiresti keereldes tema peal olevasse, kokilli kititud ja tinavihiga koormatud kivisse nakkab, seda pisut kulutab ning annab sellele läike, eriti kui kivi (toetades käe kangile, mis kivi kindlalt vastu ketast hoiab) ketta liikumisele vastupidises suunas edasi-tagasi hõõrudes vastu ketast suruda." Sõna saab lihaks!

Keel säilitab sügavaimaid jälgi inimese arengust. Märtsi algul levitas Rein Raud välisuudist, et inimene ei eristanud muistsel ajal sinist värvi. Filoloog ja semiootik Vjatšeslav Ivanov, kes eeldab, et just keele alusel kujuneb ka inimkultuuri sümboolika, märgib: „Kui keeles on sõnu punase kohta, siis on seal kindlasti ka terminid valge (heleda) ja musta (tumeda) jaoks." Semantiliselt aktiivseim tolles ürgses värvus(sõnade) kolmnurgas on punane. Kuid tuvastatud on ka inimkultuure, „milles must ja valge värv ei vastandu mitte punasele, vaid sinisele (ja kollasele), nagu vanas Hiinas". (Ivanov 1983: 10) Kui muiste kulutati hiigelvarandusi hankimaks Afganistanist lasuriiti, siis on küll mõttetu väita, et sinist värvi ei nähtudki.

Keskaja loetumaid autoreid Sevilla Isidorus võttis 600. aasta paiku kokku antiigist säilinud teadmised ja täiendas neid ristiusu klassikutelt saadutega oma entsüklopeedias „Etymologiarum sive originum libri XX”. Kümnes raamat algab näitega: „Täiesti õige, et sõnade päritoluga tegelevad filosoofid, sest näiteks inimene saab nime „inimsusest”, tark „tarkusest” - esiteks tuleb ju tarkus, alles teisena tark. Ometi seletab mõnel puhul sõna spetsiifilise tähenduse tema algupära, näiteks kui inimese kohta öeldakse homō selle järgi, et ta on maamullast tehtu: $a b$ humō, ja niisiis teda kutsutakse „inimeseks” täiesti kindlal põhjusel. Selliseid näiteid oleme toonud siin teoses.”

Tõepoolest, lad homō < humus (vrd humanus) < kr v́w'märgama, niisutama'. See ühtib ürgse ettekujutusega, et inimene on sündinud (märjast) maaelemendist; nagu ütleb piibelgi (1Ms 2: 7): „Ja Jehoova Jumal valmistas inimese, kes põrm on, mullast..."

Ent ka ebateaduslikud rahvaetümoloogiad väärivad filoloogi tähelepanu - ja võib-olla eriti just need, sest spetsiifilist kultuuriloolist huvi ei paku mitte üleajaline lingvistiline tõde (ehkki ka see on hädavajalik keeleajalooline teadmine), vaid ebateaduslikud, st raskesti taastatavad arusaamad, mida omal ajal tõeks peeti: mis tähenduses sõna toimis psüühilise tegelikkusena ja võis säärasena mõjutada ka füüsilist tegelikkust. Siin puutub filoloogia kokku etnoloogia, folkloristika ning usundilooga. Ja mille kõigega veel! - „Seejärel rääkis ta väga kiitvalt Karl Schönest, noorest Leipzigi filoloogist, kes olevat kirjutanud töö kostüümidest Euripidese näidendites..." teatab Eckermann 11. II 1831 Goethest.

\section{Filoloogi psühholoogia}

Filoloogia ei tõlgi teksti ju mitte ainult füüsiliseks, vaid ka psüühiliseks reaalsuseks. Siin etendab võtmerolli filoloogiline intuitsioon, see keelekompetentsi täiendav üldistusvõime, mis avaldub toimetulekus lingvistiliste ülesannetega, alates ristsõnade lahendusest (kus läheb tarvis determinatiivset mõtlemist) kuni maiade kirja dešifreeringuni (kus märkide topoloogilised teisendid nõuavad paleograafilt lisaks ka visuaalset intuitsiooni); alates kapten Granti 
pudelipostituse (lünkliku teksti) taastusest kuni oskuseni ära tunda võõrkeelse lause tuumsõna (semantiline „lausemaastik”) või koostada belletristikat lugedes ettekujutus autorist kui kirjanikuga mittesamastatavast immanentsest tekstifunktsioonist (Priimägi 2015). (Autorikujundi-teadvuse kadu kroonib kohtukaasus, kus kirjanikust isik - Kaur Kender - pannakse vastutama oma trükitud sõnade eest ja teksti ei käsita ilukirjandusena enam ei lugejad ega kirjanik ise, üksmeelselt nähes selles pelgalt meditsiinilist anamneesi, kirjaniku vaimse tervise seisundi dokumenti, mille alusel ta tuleb kas ravile saata või isoleerida.)

Ja teiseks filoloogi „tegelikkus $\leftrightarrow$ tekst”-tõlke suutlikkuse mõõduks on filoloogiline empaatia. Toosama, millest räägib Collingwood, et selleta pole taastatav ajalooürikutetagune tegelikkus. Aga empaatilise visioonita ei saa mõista ka näiteks Hegeli „Vaimu fenomenoloogiat” (Priimägi 1990: 3-4). Ilma selleta pole arusaadav ilukirjandus kui selline, sest filoloogiline empaatia pole muud kui intellektuaalne ning emotsionaalne indutseeritavus. Belletristiline tegelaskuju ei saa olla psüühiliselt peenem kui tema looja kirjanik. Ega ka mitte psüühiliselt peenem kui tolle lugeja. Ent ilukirjanduslikku lugemisoskust pole loodus kinkinud mitte igaühele ja vaimuvalgustuslik république des lettres ei ole mitte demokraatlik, vaid aristokraatlik vabariik.

Filoloogi aristokraatne suveräänsus võimaldab sundimatult, loomuliku keelelise intelligentsuse toel aru saada murdetekstidest. Seal, kus keelekoid otsivad sõnaraamatut ja luupi, kuuleb filoloogiline kõrv keelemuusikat ja tabab tähendusi kontekstuaalselt: „Läksin venda katsumaie, / kas on venda karjapoissi / või oros obosepoissi. / Vend nägi minu tulema. / Vend ai karja kalda'asse, / obosed ai alla orgu" (Tedre 1999: 142).

Teisalt realiseerub filoloogiline vabadus licentia poetica's. Nagu igasugune vabadus, ei kujuta seegi endast anarhiat, vaid pigem tunnetatud paratamatust. Mitte kõike keeleliselt võimalikku ei saa nimetada luulevabaduseks. Sinna viib köielkõnd mööda nähtamatuid, üksnes sisetundega tajutavaid konnotatiivseid ja grammatilisi seoseid. Samuti nagu klaverimängus ei ole vajutus valele klahvile enam mitte improvisatsioon, vaid viga.

Uudissõnadegi juurduvus sõltub nende filoloogilisest adekvaatsusest. Mitte kõik Aaviku evitised ei sobinud meie keele struktuuris oma tähenduspessa. ${ }^{1}$ Ei lähe läbi ka kogu „sõnause”-saak (milline värd! - Lennart Meri poleks säärast sallinud).

\section{Filoloog kui teadlane}

Kreeka sõnas „filoloogia” tähendab -logos keelt, kusjuures „-loogiat” ei saa tõlkida „umbkeelsuseks”. Filoloog peab olema suverään ka keele elemendis. Tema teaduslik väärtus sõltub iseenesesse investeeritud ajast, mis suuresti on kulunud keelte õppele. Selgesti sõnastas Goethe kontrastiivse lingvistika põhitõe: kes võorkeeli ei tunne, ei tea mitte midagi oma emakeelestki. „Võõrkeeli," ütles ta mitmuses. Meil hakkab maad võtma umbkeelsus oma kahes matslikus vormis: eestikeelne umbkeelsus ning eesti-ingliskeelne umbkeelsus.

Filoloog on keelearistokraat. Aga masside ülestõus on alanud, lumpen kehtestab end. Mati Hint (2005): „Eestis pole soome-ugri keelte uurimise pers-

\footnotetext{
${ }^{1}$ Ühe evitise kordaminekust vt Priimägi 2010b.
} 
pektiiv kaugeltki helge... Sama tuleb väga tungivalt ütelda saksa keele oskuse allakäiku jälgides. Nüüd on võimalik platseeruda eesti keele uurijaks saksa keelt oskamata - nonsenss, mis okupatsiooniaegses [nõukogude] ülikoolis oli välistatud. Eesti ja Läti kuuluvad selgelt saksamõjulisse kultuuriruumi. Ka vene kõrgkultuuril, Peterburi konservatooriumil jne on olnud oma osa moodsa Eesti kujunemises. Ühemõtteline inglise keele eelistamine ähvardab matta kõik eesti kultuuri komponendid pinnalise ameerikaliku massikultuuri alla."

Filo- sõnas „filoloogia” tähendab uudishimu. (Kreeka $\varphi \iota \lambda \dot{c} \omega$ tõlgitakse tavaliselt 'armastama', aga esineb Pindarosel ja Herodotosel ka tähenduses 'mingile tegevusele pühenduma'. Sisuliselt on tegu uudishimuga: armastus polegi ju muud - kui kaob uudishimu kellegi või millegi vastu, siis on ka armastus läbi.)

Uudishimu on iga teaduse alus ning algus. Sellest uurivast, uuele avatud vaimuhoiakust võrsub huvi, edasi kriitiline uuring ja viimaks teaduslik tõdemus. Sama rada pidi sünnivad ka filoloogid.

Keel on filoloogi põhimaterjal, tema peamine tööriist aga on mälu. Mälu toore pole mitte keel, vaid kogemus. Montaigne ütles, et ta ei saa vahendatud kogemust lugeda kehvemaks kui vahetut. Filoloogia on vahendatud kogemuste maailm. Sealt kogutakse teadmistepagas ajapikku. Seepärast ei saa põlvkondade väljavahetus filoloogias aset leida „plats puhtaks!” loosungi all. Seda rõhutas Goethe 30. VI 1824 von Müllerile, Coudrayle ja Meyerile: ei saa autoriteetseks pidada väga noori filolooge - alles vähemalt viiekümnesed on siin patres curiae. Proovitagu seda tulla ütlema tänapäeval! Mõned parandused, mida noored filoloogiharidusega keeletoimetajad on teinud mu kirjutistesse, pole näidanud muud kui nende hariduse puudulikkust, mida korvab häbematu iseteadvus - ülikoolidiplomiga kinnitatud õigus olla ise rumal ja näidata mind endasugusena. Sellistest vägistaja-toimetajatest pagemaks loobus kunagi ajakirjanduse rostrast deklaratiivselt Jaan Kaplinski.

Kes on filoloog, võib määratleda niihästi abstraktselt kui ka konkreetselt, per demonstrationem, näidete abil. La Fontaine avaldas pühendusluuletuses 1687 tunnustust Pierre-Daniel Huet'le kui oma aja suurimale filoloogile, Bayle ülendab kirjas Lamonnoye'le (20. I 1698) suurimaks prantsuse filoloogiks „pärast viimatist tagakiusamist” hugenotliku Sédani akadeemia kreeka keele professori Jacques Du Rondeli, Goethe mainis 19. IV 1824 Eckermannile, et nende aja suurim filoloog on Friedrich August Wolf, „Homerose küsimuse" püstitaja. Aga kes noid tegelasi teab? Filoloogia laiad piirid hõlmavad ka märksa värvikamaid, mitmekülgsemalt tegevaid figuure, kes jätavad varju kitsalt erialainimesed. Kes on Huet teda ülistanud La Fontaine'i, kes on Du Rondel tollesama Bayle’i või kes on Wolf olümposlase Goethe kõrval? Sest noodki olid filoloogid. Kui mina peaksin mõne nimetama, siis viitaksin muude hulgas Mihhail Gasparovile ning Juri Lotmanile (Priimägi 1982). Isiksuse dimensiooni humanitaarteaduslikus mõtlemises ei tohi alahinnata.

Filoloogias, nii nagu humanitaarias üldse, etendab isiklik autoriteetsus (verba magistri!, ipse dixit!) märksa olulisemat osa kui reaalteadustes, kus ainsaks autoriteediks on tulemuste korratavus. Võime sisendada aukartust oma teadmiste täielikkuse ja kogemustepagasi kaalukusega iseloomustab filoloogia suurkujusid. See annab neile eriõiguse, licentia scientifica. Luther oma lauakõnedes tsiteerib piiblit peast ja sageli mitte sõna-sõnalt ning asi ei ole mitte niivõrd selles, et tema ise tõlkis pühakirja emakeelde ja võib iga hetk oma tõlke ümber sõnastada. Asi on pigem jumaliku ilmutuse funktsionaal- 
suses, mitte formaalsuses, mitte tähenärijalikus pedantismis, mille abil pimedusjüngrid ei suuda esile tuua vähimatki vaimu valgustavat.

Teadus püsib siiski kindlatel alustel. Raudkindlust sisendavad vana, tsaariaegse kooli filoloogid, kelle kirjutistest on tunda vankumatut asjatundmist, lüngatut allikate valdamist ja viimseni vastutust iga oma väite eest. Kõik nende jutt on assertooriline, suverääni õigusega lausuvad nad käsiteldavas küsimuses lõplikku, edasikaebamatut. Isikliku autoriteetsuse tagavad teaduslik kapatsiteet ja teaduslik ausus. Iga nende raamat on usaldusväärne oppik, iga artikkel kui seaduseparagrahv - selline eeskuju sisendab aukartust ka veel tsaariaegse hariduse omandanute käe all õppinute puhul. Kolmanda põlve õpilased juba kaotavad veenvust. Aga nende võidelda on filoloogia edasielu eest.

Aukartusena ilmneb südametunnistus. Tänapäeval, kus harimatust enam ei häbeneta, progresseerub teadusliku süüme poroos. Nõnda kaob humanitaarse teadmuse väärtusskaala, autoriteetide hierarhia. Ei ole enam „filoloogia paavsti”.

„Tema on ju paavst!" hüüatas mu ladina keele õppejõud Ülo Torpats, kui rääkisin talle, et antikvariaadist õnnestus osta Georgese ladina-saksa sõnastik. Ning Ülo Torpats ise. Õpetas, mis ta õpetas, aga minusse sisendas ta väärtuslikema, mida üks magister philologiae võib edasi anda - häbi mitte teada saada, häbi mitte olla teada saanud, kui teist korda küsitakse sedasama. Lotman tunnistas, et mõnikord olnud tal piinlik Puškini ees... Sealtpeale, kus kaob too piinlikkustunne ning uinub faustlik vaim - „meie kirglik intentsioon (Gerichtetsein), kolmanda mõõtme paatos" (Spengler 1923: 491) -, sealtpeale sureb filoloogia.

\section{Filoloogia ja humanism}

Euroopa põhiväärtused on antiik, kristlus ja faustlik vaim. Rohkem neid ei ole. Ja kui üks ära võtta, kukub kokku meie Euroopa identiteet, tema kultuuriline isedus. Igaühega neist seostub suure filoloogi nimi: Cicero, sõna humanitas autor; Erasmus, kreekakeelse Uue Testamendi kriitilise väljaande toimetaja; Goethe, kes Vana Testamendi Iiobist ja renessansiaegsest nigromandist lõi Euroopa Inimese sümbolkuju, Fausti.

Poliitikutel on muidugi oma ilmapilt. Kui Sven Mikser (2016) kuulutab, et on „aeg kaitsta Euroopa väärtusi”, siis tõmbun ma valvele. On ka põhjust. Üks tema kolleege näiteks, keegi vabaerakondlane (Kaldma 2016) kirjutab pealkirja all „Euroopa väärtuste kaitsjad peaksid selgeks tegema, mis asjad need Euroopa väärtused on”: „Hirmsasti tahetakse kaitsta näiteks kristlikku religiooni. Ohustatud on see ilmselt tõesti, kuid ei kuulu Euroopa väärtuste hulka, pigem vastupidi, Euroopas on au sees ilmalikkus." See sõjakalt lauda löödud postulaat pärineb küll ookeani tagant.

Antiik annab meile oskuse näha ja hinnata, mis suunas Euroopa ühiskond areneb - see on antiigi tähtsaim ning püsivaim roll. Ja kristlus annab meile oidu mõista, mis suunas Euroopa ühiskond arenema ei peaks.

Ameerika ideoloogide ja nende käsikute jutud „euroopalikest väärtustest” („demokraatia”, „isikuvabadus”, „inimõigused”...) toovad meelde Mephistophelese öeldu (vv 1995-1996): Denn eben wo Begriffe fehlen, / Da stellt ein Wort zur rechten Zeit sich ein - „Just seal on mõnus tulla sõnadega, / kus mõtet pole 
ülepea" (Goethe 1967: 100). Niisuguseid libesõnu (Tõnjanovi ütlus), sääraseid libapoliitikuid paljastada jääb filoloogi kui võitleva humanisti südametunnistusele. Just sellel filoloogilisel ekraanil linastub mõistuse harmagedoon, millest räägib Nietzsche, nentides kokkuvõtteks („Der Wille zur Macht”, § 685), et loomuliku valiku printsiip annab inimühiskonnas paraku Darwini kuulutatule vastupidise tulemuse: ,just need, kes on tugevaimad ning õnnelikemad, on nõrgad, kui nende vastu tõusevad organiseeritud karjainstinktid, nõrkade pelglikkus, massiline ülekaal.”

\section{Minetus}

\section{Filoloogiline formalism}

Filoloogilise suveräänsuse, üleolekuveendumuse murendus kitsarinnaliseks väikluseks ilmneb sisutu formalismina, kammitseva konventsionaalsusena. Teadus on avastusest muutunud vormistuseks! Uusimal ajal nõuavad pedandid koguni, et raamatuviites oleks ära näidatud ka ISBN - no milleks? Ja nüüd peab isegi illustratsiooni trükiallikat viitama, just nagu kütaks kedagi vajadus üle kontrollida, kas pildil on ikka kujutatud Michelangelo „Taavetit”! Iga kord, kui öeldakse, et mu teksti on raske mahutada väljaande sängimõõtudesse, meenub mulle Beethoveni vastus viiuldajale, kes tuli kurtma, et helilooja sonaati on võimatu viiulil mängida: „Mis läheb mulle korda teie kuradi viiul!"

Selle tulemusel ilmub tonnide kaupa eeskujulikult tabuleeritud kvaasi- või lausa pseudoteaduslikku nonsenssi, mille eest jagatakse doktorikraade ning asinus asinum gaudet.

Avastuse peavad asendama viited varem öeldule, iga uut mõtet kahtlustatakse plagiaadiks. Aga mõni idee võib sündida ka omaenese lihtsusest. Leibniz ei pruukinud kahendsüsteemi üle võtta hiinlaste $Y i$ jing’ist - binaarsust ei pea laenama Kaug-Idast, see võib loogikul endalgi pähe tulla. Näitelause Ich habe keine Zeit puhul ei pea tingimata viitama, et see on võetud Feuchtwangerilt.

Teadus areneb avastuselt avastusele (mitte publikatsioonilt publikatsioonile). Kuidas on juhtunud, et teadustöö, ka filoloogilise teadustöö väärtust mõõdab nüüd tsitaatide ja viidete arv, mis sageli varjab kirjutaja mõttelagedust? Lõin lahti Ero Liiviku (2012) artikli „Usalduse kadu viib ühiskonna küünilise resigneerumiseni”. See koosneb üheteistkümnest lõigust. Seitsmest leiame: „Seymour Martin Lipset on öelnud, et”, „Wolfgang Streeck väidab, et”, „Carl Schmitt on osutanud, et”, „Sheldon Wolin on toonud käibele mõiste”, „Olukord tuletab meelde Pierre Bourdieu mõtet, et”, „Bourdieu on osutanud, et”, „Slavoj Žižek on kirjutanud, et”... - toodud nimed pole ju enamat kui Facebooki „laigid".

Idee vaegust varjab viidete rohkus, avastuse puudus on mähitud tsitaatide kassikangasse, just nagu kehtiks reegel, et mida keerukam referaat, seda kõvem teadus. Aastal 2012 avaldas Tallinna Ülikooli kirjastus Lars F. H. Svendseni „Igavuse filosoofia”. Avan juhuslikult leheküljed 46-47 ja loen: „Robert Nisbet arvab”, „kuulutab Georges Bernanos”, „Nietzsche mainib”, „Joseph Brodsky kirjutab”, „Talking Heads laulab”, „Simone Weil süvendab” - no mitte mingit oma panust (ehk ainult see, et Weili tsitaat on väidetuga vastuolus). Ja säärast avaldab ülikooli kirjastus, trükkides „Igavuse filosoofia” kaanele 
Düreri „Melanhoolia”... Ideetus, harimatus, kultuuritus on nüüdisteaduse šibolet.

Tsiteeritavusest või õieti viidatusest on tehtud intellektuaalse kaalukuse mõõt. Seetõttu käib teadusmaailmas „laikide” kogumise hoogtöö. Näiteks võin siin osutada Tampere klassikalise kooli ladina keele lektorile Jarkko Vilkkiläle (Haridus 2011, nr 4, lk 35), kes tsiteerib Mark Fisherit, kes omakorda viitab Frederic Jamesonile. Niisiis: Jamesoni tsiteerib Fisher, keda tsiteerib Vilkkilä, kellele viitan siin mina. Kolmekordne referents, kolm kärbest ühe hoobiga! See meenutab August Jakobsoni muinasjuttu, kus peremees käskis sulast: loputa supikauss sooja veega ning anna koerale, siis loputa külmaga ning anna sandile... Ja säärase loputuse loputuse meetodil saadud sandilakkega lüüakse läikima teadlase maine! Winckelmann ütles niisuguste kohta: elende Skribenten (ei ole teost oma silmaga näinud ja kirjutavad teiste pealt maha). Tegema sunnib seda mainedoonorlus: pimesigi viidates mingile autoriteedile omandatakse talt ise autoriteetsus. Odav formalism, mida soodustab ind jahtida just kõige viimatisi allikaid, sest nendel on taga pikem riburada viidetest, viidete viidetest ja viidete viidete... viidetest. Esmaallikaid - ad fontes! - enam ei loeta, ei osata. Seetõttu imetletakse ja levitatakse pseudoteaduslikke moevälgatusi („neurolingvistiline programmeerimine”, „hübriidsõda”, „pildiline pööre"), mis teadusliku mõtte arengu tundjale valmistavad piinlikkust.

Tsiteeringul ja tsiteeringul on siiski vahe: üks on kompliment („laik”), teine aga trepiaste, mida mööda tõustakse teaduses uuele tasemele. Üks on kohapealne edvistus, teine edasiviiv, mõtet virgutav ja taganttõukav. Seda põhimõttelist väärtusvahet statistika ei tee. Mis tõesti mõõdab viiteallika väärtust, on tema ajaproov, olulisuse, produktiivsuse kestus. Aquino Thomas püsib tänapäevani produktiivne (lad pro-ducere 'edasi juhtima'), aga kõik need mõnekümne aasta eest nii populaarsed Derridadad ja Lacancanid on lavalt lahkunud. Allikate vanus mõõdab kultuurimälu sügavust: reaalteadustes hinnatakse võimalikult viimatise, up-to-date-üllitise referentsi, humanitaarteaduses reedab viidatud allikate „aktuaalsus” vaid õhukest kultuurikihti. Eruditsiooni näitab sügavam vaimukünd, põhjalikum hingekultuur.

Fundamentaalsetel allikatel (nagu piibel või koraan) ning aluslikel autoritel on oma, teksti väljaandeaastast või ilmumispaigast sõltumatu kaanon põhimõttel sapientibus sat. Nõnda kujuneb filoloogiline viiteaparaat aristokraatlikuks salakeeleks (nagu rooma ülikud läksid üle kreeka keelele, kui teenijad ruumi sisenesid), mille järgi üksteist ära tuntakse. Iga kristlik haritlane teab, mida tähendab „1Ko 1: 13”; iga antiiki tundev filoloog suudab viite „250 C” järgi Platoni „Phaidroses” lahti lüüa kirjakoha, kus tehakse juttu kaasasündinud iluidee kustumatusest; iga medievist mõistab üheselt lühendit „S.th. II, q. 8, a. 2”; ühelegi frankofiilile ei jää arusaamatuks „Littré s.v.”. Kes väga soovib, leiab Goethe vestlused WA viiendast osast, ja kes ei soovi, sellele pole ka köite ega lehekülje numbri viitest kasu. Pangem tähele: mida detailsem tsitaat, seda kõrvalisem autor (mõnd viidet on lausa piinlik koostada). Lõpuks aga muudab internet raamatukoguna liigseks kõik bibliograafilised kirjed ning aristokraatliku etiketi „MPL VII: 82 A” asemel piisab plebeilisest lühiühendusest: http://www.documentacatholicaomnia.eu/02m/02400320,_Lactantius,_De_Ira_Dei,_MLT.pdf.

Muidugi, inimene võlgneb hariduse ja kultuuri oma eelkäijatele ning peakski üles näitama tänulikkust, meenutades neid. Goethe hoiatab (WA I 42.2: 205): „Pereant qui ante nos nostra dixerunt! - Midagi nii imelikku 
võiks öelda vaid keegi, kes kujutleb end olevat autohtoonne. See, kes peab auasjaks pärineda arukatest eelkäijatest, möönab neile ometi vähemalt sama palju inimmõistust kui iseendale.” Kui küsimusele „kelle õpilane sa oled?” vastatakse anonüümse vaikusega, räägib see õpetaja tühisusest. Sokratese surmamõist oli Aristotelese sõnutsi kuritegu filosoofia vastu. Kas oskame nimetada nüüdismaailmas filoloogi, sõltumatut, suveräänset mõtlejat, kelle kohta saaks sama öelda? Kelle kõrvaldus oleks humanitaarteadusmõrva mõõtu?

Kui ühiskonnast kaob vaimuaristokraatlus, sureb välja ka filoloogia. Jääb institutsionaliseerunud ja formaliseerunud publikatsioonide rohkendus ilma eredate avastusteta, sest avastuskirest ning andumusest pole enam jälgegi. Uute suurte küsimuste puudus pole ju muud kui teadusliku julguse puudus. Maad võtab teaduslik argus (kartus ebaoriginaalsuse paljastuse ees) ja ringkaitse (Goethe: Wechselnichtigkeit, vastastikune tühisus), konventsioon ja „kuldse kesktee” mentaliteet. Aga mis tohib teaduses üldse olla „kuldne kesktee"?

\section{Ilu õigsus}

Filoloogiline teadvus kätkeb sõnavara kujundlikku potentsiaali, milles säilib denominatsiooni algne, ürgne pildilisus ja mis seega kujutab endast poeetilise kreatiivsuse keeleressurssi. Kuidas seletada välismaalasele, miks „nosida” saab leiba, aga mitte maasikaid, või et „vemmeldama” saab öelda vere kohta, aga „vemmeldas vastu ust” kõlab idiootlikult (vrd „plaksutas ühe käega”).

Sama võõrkeeltes. Värvikat näidet pakub Vanemuise viimatise „Aida” lavastuskontseptsiooni vägivaldsus: etiooplaste alistust seal libretos tahtis Madis Nurms päevapoliitiliselt seostada Ukraina sõjaga ja tegi nimitegelasest rahuvõitleja. Tõesti, Verdi ooperi viimane pilt lõpeb Amnerise sooviga elusalt hauda müüritud Radamesile: Pace, pace! Seda sõna tuleb siin mõista nagu ladina epitaafil Requiescat in pace - eesti „Puhka rahus!”, inglise Rest in peace! Homonüümia kahes viimati nimetatud keeles ilmneb, kui vaadata muid: antud seoses on õige vene покой, mitte мup, saksa Ruhe, mitte Frieden. Schilleri „Don Carloses” (III 8) ütleb markii de Posa kuningas Felipele „surnuaiarahu", die Ruhe eines Kirchhofs, otse vastandades seda mõistele Frieden, mille sisu nii tema kui ka Schilleri ideaalina pärineb Kanti filosoofilisest projektist „Zum ewigen Frieden” (1795). Lavastuskontseptsioon osutub väärakaks filoloogilise harimatuse tõttu!

Keele kujundlikku potentsiaali realiseerib kirjandus, eeskätt luule. Sedamööda, kuis progresseerub „pildiline afaasia”, minetavad sõnad semantilise sügavuse ja tekst lameneb. Just seda näeme taasiseseisvunud Eesti luules, kusjuures poeetilisuse kadu pole mitte autorite esteetiline valik ega halva maitse nakkus, vaid süvenev filoloogiline kuulmispuue ning ühtlasi andetuse lettre de cachet. Meie nüüdisluuletajad on halvad, sest nad on kehvad filoloogid!

Aga luulelisus, poeetilisus on üldse kirjanduslikkuse tagatis. Seetõttu ei kohta ka proosas enam ilukirjandust: viimase veerandsajandi romaanidjutustused - täpselt nii nagu luulegi - kujutavad endast halle ajakirjanduslikke tarbetekste, olukirjeldusi, mis ei võimalda kunstispetsiifilist elamust (Priimägi 2014). Siiski annavad kriitikud nende eest auhindu. Ei maksa küll kiruda peeglit, kui lõust viltu. Aga kui viltune lõust paistab kõverpeeglist, siis paistab ta kahekordselt jube. 


\section{Tõlke väärtus}

Igat emakeelt toidab oma eriline filoloogiline mütseel, mistõttu IX sajandi araabia kirjanik ja filoloog al-Jāhiz pidas tõelise luule tunnuseks tõlkimatust (Graziosi 2014: 209). Meie oleme näinud, kuidas adekvaatselt eestindada saab ka luulet, aga selleks peavad olema kutsutud hiilgava filoloogilise tajuga eesti eurooplased: August Annist, Betti Alver, Georg Meri, Rein Sepp, August Sang, Jaan Kross, Ain Kaalep - kui nimetada üksnes neid esimese suurusjärgu tähti meie tõlkijate plejaadist. Miks pole täna nendele mitte kedagi kõrvale panna?

Tänapäeval laotakse (enamasti ingliskeelsed) sõnad ladusasse eesti grammatikasse, aga pahatihti välgub välja, et tõlkija ei tunne valdkonda, mida tekst käsitleb („Venezia maalikunsti meenutav koloratuur” - Ricketts 2006: 18; „keda kunstnik hüüdis Ludwig XIV, kuna naine meenutas talle Prantsuse Päikesekuningat”, „karusnahkne rüü iseloomustab Ristija Johannest” Weyers 2006: 74, 92), eestindaja ei tea võortekstis esinevate sõnade tähendust („riigid, mis kontrollisid ümbrusesse jäävaid põllumajanduslikke maid”, jumalanna Inanna kui Uruki „patroon” - McIntosh, Twist 2001: 46-47) ega suuda läbi oma sileda sõnakudumi paista lasta öeldu mõtet („Kiri leiutati Sumeris, mis tähendab, et see hakkas arenedes peegeldama sumeri keelt" - McIntosh, Twist 2001: 47).

Kahvatab arusaam kirjandusklassikast. Eesti Päevaleht hakkas välja andma romaanisarja „Aegumatud armastuslood”. Võiks arvata, et „aegumatus" tähendabki üleajalist klassikat. Kuid lugeda pakutakse vaid teise- ja kolmandajärgulisi autoreid, enamasti naiskirjanikke, valdavalt ingliskeelseid. Ei leia me kolmekümne pakutava köite kaanelt ei Longose, ei Dante, ei Stendhali nime. See on meie mentaliteedi angloamerikaniseerumise, lamenemise demonstratsioon!

\section{Nimekultuur}

FAUST: Mis on su nimi? MEPHISTOPHELES: Väiklane on, näib, nii sellel küsida, kes sõnu vihkab, kel näilikkus nii hinge pihta käib, kes olemust vaid teada ihkab.

„Faust I”, vv 1327-1330

Kultuurimälu on kodeeritud pärisnimedesse. Aga kultuuri kodifitseeriva isikunimevõrgustiku kude on ebaühtlane: isikud, kes seal nominaalselt suhestuvad ning ühenduvad - selle struktuuri elemendid -, on eri valentsiga. Väga kõrge valentsarvuga nimesid kannavad kultuuriloo suurkujud. Valentsarvu kahanemise järjekorras sisenevad kultuuriteadvusse teise-, kolmandajne-järgulised tegelased, kelle kohta luuleloos on olemas isegi oma termin: poetae minores. Nende tundmine on erudiitide privileeg. Kuni siis viimaks tulevad need, kelle kohta Vergilius ütleb Dantele (Inf III, 49, 51): Fama di loro il mondo esser non lassa.../ non ragionam di lor, ma guarda e passa. ${ }^{2}$

\footnotetext{
${ }^{2}$ Johannes Semperi tõlkes: „Mis nad kord olnud, on kui suitsuvine... / Kuid küllalt! Vaata kord ja mööda mine!” (Alttoa 1962: 431).
} 
1960. aastatel peeti Eesti Televisioonis maha kilb „Naapurivisa”, kus eestlaste võistkond andis muusikaküsimusele vastuseks „Bach”, mida kohtunik püüdis valeks lugeda, sest ei olnud öeldud, milline Bachidest. Seepeale käratas entsüklopeediliste teadmistega Hardi Tiidus: kui „Bach”, siis mõeldakse heliloojana ikka suurt Bachi; ainult kui peetakse silmas mõnd teist, öeldakse ette „Carl Philipp Emanuel” või „Johann Christian”. Samamoodi käib „Straussi valss” küll näiteks Johann Strauss junior’i valsi „Ilusal sinisel Doonaul” kohta, aga „Radetzky marssi” ei tituleerita „Straussi marsiks”, sest selle kirjutas senior. Saksa kirjanik „Mann” on kõigepealt Thomas, alles siis Heinrich ja viimaks Klaus. „Lotmaniks” jääb esmajärjekorras siiski Juri Mihhailovitš.

Kultuurimälu kaotus algab nimede hierarhia segiminekust. Pärisnimi muutub indeksmärgist tingmärgiks, signaalist müraks. Viimatise sajandivahetuse künnisel koostasid mitmed väljaanded nimistuid inimkultuurile tähtsaimatest isikutest. LIFE Magazine järjestas 100 tegelast, kes panustasid enim teisel aastatuhandel. Tollase Tallinna Pedagoogikaülikooli tudengikandidaadid andsid sisseastumiseksamil esikümne kohta järgmisi kirjalikke vastuseid: 1. Thomas Alva Edison - üks maailma suurimatest leiutajatest, sakslane, kes avastas elektri; 3. Martin Luther - 1517 Ameerikas tegutsenud Lõuna-Aafrika liider, kes nõudis vabadust mustanahalistele; 4. Galileo Galilei - USA astronoom, kes leiutas pikksilma ja galeidoskoobi; 5. Leonardo da Vinci - XVIII sajandi itaalia kunstnik, „Päevalillede” autor; 6. Isaac Newton aurumootori leiutaja; 8. Louis Pasteur - naisrevolutsionäär; 9. Charles Darwin - XVIII sajandi ameerika füüsik, Darwini seaduse autor...

Nimi on filoloogia. Ja filoloogiat ei ole ilma kultuurimäluta.

\section{Kultuurimälu}

Kui me siin kirjeldatud moel käsitame filoloogiat ja küsime, millest on tingitud tema allakäik, siis selgub vastuseks: radix omnium malorum on humanitaarse üldhariduse kadu tänapäeva ühiskonnast. Globaliseeruv tsivilisatsioon ei vaja Euroopa kultuuri.

Vana-Rooma eriti peentel pidudel serveeriti üht kala, aga mitte söögiks. Lauale kanti ta hõbeliual, veel elus, purpurpunane. Ja siis lasti tal aegamisi surra, nautides, kuidas eksoot aeglaselt üha kahvatumaks tõmbub... kuni ta lõplikult hinge heites muutus läbipaistvaks, sulandus liua hõbedasse. Kujundina võiks see kirjeldada filoloogiaga, meie Euroopa kultuurimälu suurima ühisnimetajaga toimuvat. Erutust õigustab tõsiasi, et just ühiskonna murrangulistel perioodidel aktualiseerub mäluvajadus, hakkab helisema alarm, et tuleb päästa oma kultuurkondlik isedus. Tuleb mäletada üle sajandipiiride.

Üheksateistkümnes aastasada vajas oma algusaastatel kaheksateistkümnenda seletavat sõnaraamatut. Selle vajaduse ilmseks väljenduseks sai „Kriitiline ja süstemaatiline õukonnaetiketi sõnaraamat... ehk Endise etiketi ja kommete vaim võrrelduna nüüdisaegsega" (1818), mille koostas hilisema Prantsuse kuninga Louis-Philippe'i kasvatajanna, tänini lastekirjanikuna tuntud krahvinna de Genlis. Ja kahekümnenda sajandi algul ütles vene sümbolistlik luuletaja Blok (2001: 729): „Juba 1901. aasta jaanuar seisis hoopis teise märgi all kui 1900. aasta detsember, kohe sajandi algus oli täis oluliselt uusi endeid ning aimusi." 
Mihhail Lifšits (1986: 141) täheldab, et igale ühiskondlikule äkkmuutusele järgneb teatav üleminekuaeg, kus haritud vähemik on veel võimeline ellu kutsuma kõikehõlmavaid süsteeme, tõelisi murrangujärgse ülesehitustöö entsüklopeediaid. Kes on nüüdsed filoloogid-entsüklopedistid Eratosthenes, Isidorus, Suidas, ${ }^{3}$ Berchorius, Huet, Diderot, Grimm... Et meie entsüklopeedia olla internet? - Aga internet poleks suutnud koostada Wiedemanni sõnaraamatut!

Filoloogia hoiab Euroopa ühismälu. Veel tunnevad omad üksteist ära augurinaeratuse ja paroolide järgi, teavad peast Caesari „Gallia sõja” alguslauset ning oskavad retsiteerida "Quattuor aetatese” algusridu. Aga neid jääb üha vähemaks ja varsti muutuvad nad mingeiks lamed vovnik'uteks (36 üksteisele tundmatuks, enesele teadmatuks ning avalikkusele silmatorkamatuks õiglaseks, kes juudi pärimuse kohaselt on alati olemas, tagades Jumala kohalolu maailmas ning ilmutavad end, kui maailma ähvardab katastroof ja hukk).

Kultuur on saar, mida ümbritseb harimatuse ookean. Kas peaksime filoloogidena võitlema entroopia transgressiooni vastu nagu Faust oma finalistliku maaparanduskavaga (Goethe 1967: 649): „Uut elu näeb neis paigus taevavõlv, / kui koos on töös virk-julge inimpõlv / ja õide puhkeb paradiislik maa. / Las ründab voog - maast võitu ta ei saa."

Või siis tuleks loobuda säärasest prometeilisest utoopiast ja sulguda privaatsesse optimismi, mida jutlustab Candide: „Me peame harima oma aeda.”

Solon, kellel ei õnnestunud ateenlasi veenda, et Peisistratose türannia on kurjast, istus täis relvis oma lävele: „Kui teie ei kaitse oma linna, siis mina kaitsen oma kodu.” Ja kui talt päriti: „Millele sa loodad?”, vastas ta: „Oma vanadusele."

\section{Kirjandus}

Alt toa, Villem (koost) 1962. Keskaja ja vararenessansi kirjanduse antoloogia. Tallinn: Eesti Riiklik Kirjastus.

B a u kh a ge, Manon 2005. Der Bibel-Code. - Peter Moostleitners Magazin P.M., Detsember, lk 35-41.

B e n v e n is t e 1974 = Эмиль Бенвенист, Общая лингвистика. Москва: Прогресс.

B lok 2001 = Александр Блок, Поэзия, драмы, проза. Москва: ОЛМА-ПРЕСС.

Go eth e, Johann Wolfgang 1967. Faust. Tlk August Sang. Tallinn: Eesti Riiklik Kirjastus.

Gra zi o si, Barbara 2014. Olümpose jumalad. Ajalugu. Tallinn: Imeline Ajalugu. Gurevits 1984 = Арон Яковлевич Гуревич, Категории средневековой культуры. Москва: Искусство.

Hin t, Mati 2005. Inglise keel haridust ei asenda. - Eesti Päevaleht 19. XII.

Iv a n ov 1983 = Вяч. Вс. Иванов, Художественное творчество, функциональная асимметрия мозга и образные способности человека. - Труды по знаковым системам XVI. Текст и культура. (Tartu Riikliku Ülikooli Toimetised 635.) Tartu: Tartu Riiklik Ülikool, lk 3-14.

Kald m a, Tarmo 2016. Euroopa väärtuste kaitsjad peaksid selgeks tegema, mis asjad need Euroopa väärtused on. - Delfi 18. III.

${ }^{3}$ Nõnda kutsutakse kokkuleppeliselt „Suda”-nimelise bütsantsi entsüklopeedia võibolla kollektiivset autorit. 
Ka plinski, Jaan 2016. Mõni mõte Hiina kultuurist, ideoloogiast, ideaalidest. Sirp 8. IV.

Lifš its 1986 = Мих. Лифшиц, Собрание сочинений в трех томах, II. Москва: Изобразительное искусство.

Liivik, Ero 2012. Usalduse kadu viib ühiskonna küünilise resigneerumiseni. Sirp 10. VIII.

Lotman 1982 = Ю. М. Лотман, Редакционное примечание. - Труды по знаковым системам XV. Типология культуры. (Tartu Riikliku Ülikooli Toimetised 576.) Tartu: Tartu Riiklik Ülikool.

M c In t o s h, Jane, Tw i s t, Clint 2002. Tsivilisatsioonid. Kümme tuhat aastat ajalugu. Tlk Indrek Rohtmets, Tõnis Värnik. Tallinn: Varrak.

Miks er, Sven 2016. Aeg kaitsta Euroopa väärtusi. - Delfi 5. III.

Pri i mäg i, Linnar 1982. Filoloog loeb luulet. Juri Lotman: „Когда же чорт возьмет тебя!" - Edasi 13. III.

Pri i mäg i, Linnar 1990. Sõna fenomen ja muusika tagasitulek. Hegeli esteetika vaimufenomenoloogilisest tagapõhjast. - Scripta Musicalia, nr 13-14, lk 3-4.

Pri i m ä g i, Linnar 2010a. Eurooplase kultuuripõhi. Tallinna standard 2011. Tallinn.

Pri i mäg i, Linnar 2010b. Mis on süüme? - Peep Nemvalts (toim) 2010. Johannes Aavik 130. Konverents "Sada aastat hiljem: keeleuuenduse poolt ja vastu” 20. novembril 2010 Eesti Teaduste Akadeemia saalis Tallinnas Kohtu tn 6 . Ettekannete teesid. Johannes Aaviku Selts, lk 9-10.

Pri i mä gi, Linnar 2014. Rääbakad õied. - Sirp 20. V.

Pr i i m ä g i, Linnar 2015. Vene formalism ning eesti kirjandus. Formalistlik essee. - Keel ja Kirjandus, nr 1, lk 33-40.

Ricketts, Melissa 2006. Rembrandt. Suurte kunstnike galerii. S.l.: Tarian.

S pengler, Oswald 1923. Der Untergang des Abendlandes, I. Gestalt und Wirklichkeit. München: C. H. Beck'sche Verlagsbuchhandlung, Oskar Beck.

Tedre, Ülo (toim) 1999. Vana kannel VIII. Jõhvi ja Iisaku regilaulud. Tartu: Eesti Keele Instituut, folkloristika osakond; Eesti Kirjandusmuuseum, Eesti Rahvaluule Arhiiv.

W e y e r s, Frank 2006. Salvador Dalí. Elu ja looming. Tallinn: Koolibri.

Wi en er, Norbert 1969. Inimolendite inimlik kasutamine. Küberneetika ja ühiskond. - Loomingu Raamatukogu, nr 45-47.

\section{Philology that is no more}

Keywords: exegesis, etymology, Goethe, Lotman, memory, translation

Here we define „philology” as a discipline studying how reality is transformed into text and vice versa. The question of philology is wording, while its object encompasses everything accessible to verbal reference.

Philology belongs to Culture, not to Civilisation. Civilisation consists of knowledge and skills, answering the question „How to do/make it?" Culture consists of norms, orders and prohibitions, of do's and don'ts, answering in the end the question „How to understand it?" Civilisation is developed by sciences, Culture is developed by the humanities. Philology belongs to the humanities, perhaps even, considering its function of studying the relations between text and reality, as a 
meta-discipline. The conjecture that the central question of philology is „How to do/ make it?" is no less than barbaric.

Despite the globalising Civilisation, Culture will remain local (the Latin colere can, after all, be interpreted as being attached to a concrete plot of land and its deities, i.e. to a cultus). Humanities concepts will keep rooted exactly where they once germinated. „Philology” is a humanities concept born in the European cultural area, thus being Europocentric in nature. „Japanese philology” is a European meta-discipline dealing with Japanese texts. The true sense of philology, its čtvuov, will however remain rooted in European mentality.

What is the final aim of philology? This is a weighty question asking for a clear answer: The ultimate goal of philology is regeneration of the European collective cultural memory by cultivating intellectual aristocracy, by producing new lamed vovniks to keep and disseminate the basic values of European culture, which are classical antiquity, Christianity and the Faustian spirit. This is indeed an onerous social pedagogical mission of ultimate responsibility, especially under the pressure of the current Great Migration, when we witness how higher education is levelled down to vocational education and hear ever loudening voices claiming that the cultural values of Europe are just tolerance, pluralism and Americanism. Paraphrasing „Tristram Shandy”, there is no Northwest passage to the philological world.

Linnar Priimägi (b. 1954), PhD, Tallinn University, Department of Advertising and Image Studies, Associate Professor, tristan@tlu.ee 